\title{
Racial and Ethnic Variations in Knowledge and Attitudes about Genetic Testing
}

\author{
ELEANOR SINGER, TONI ANTONUCCI, and JOHN VAN HOEWYK
}

\begin{abstract}
This study was designed to shed light on whether differences in utilization of genetic testing by African-Americans, Latinos, and non-Hispanic Whites are due primarily to different preferences, or whether they instead reflect other values and beliefs or differential access. It explores the values, attitudes, and beliefs of AfricanAmericans, Latinos, and non-Hispanic Whites with respect to genetic testing by means of a telephone survey of representative samples of these three groups. The study finds clear evidence that Latinos and AfricanAmericans are, if anything, more likely to express preferences for both prenatal and adult genetic testing than White respondents. At the same time, they hold other beliefs and attitudes that may conflict with, and override, these preferences in specific situations. African-Americans and Latinos are also less knowledgeable about genetic testing than non-Hispanic Whites, and they are less likely to have the financial resources or insurance coverage that would facilitate access to testing.
\end{abstract}

\section{THEORETICAL CONSIDERATIONS}

$\mathbf{P}$ RENATAL GENETIC TESTING and genetic testing for adults raise a number of issues relevant to the provision of health care as well as the formulation of public policy. So far as public policy is concerned, the issues that will have to be addressed have to do with insurability (for example, to what extent genetic conditions will be considered pre-existing conditions, and with what implications for insurability, coverage, and rates for both health and life insurance), privacy (how information about genetic heritage can be protected against intrusion), and discrimination (preventing employers and insurance companies, for example, from discriminating against individuals on the basis of genetic information; see Canter, 1984; Draper, 1986, 1991; Uzych, 1986; U.S. Congress, 1990; Billings et al., 1992). So far as health care is concerned, the issues that arise have to do with access to care-e.g., assuring equitable access to genetic screening and testing as well as prenatal diagnosis, regardless of the ability to pay-and the relative allocation of health care funds to these technologies versus other types of preventive medical care (e.g., should everyone, or only women at high risk, have access to prenatal testing; should all women, or only those at high risk, be offered testing for the breast/ovarian cancer gene? See Institute of Medicine, 1994).
Racial and ethnic disparities in health care and health status are well documented (Williams and Collins, 1995; Williams, 1999; Krieger and Williams, 2001; Williams, 2001, 2002). Such disparities have also been noted with respect to prenatal genetic testing, which makes possible the diagnosis of a wide variety of genetic diseases and conditions and, in some cases, preventive or therapeutic action. For example, Brett et al. (1994) found, based on an analysis of 1990 birth records, that AfricanAmerican women were significantly less likely to use amniocentesis than White women were-10.9\% compared with $23.2 \%$.

One question that has been raised about this finding is whether the discrepancy in use of prenatal testing is due primarily to differential preferences on the part of Whites and African-Americans, or whether it instead reflects differential access to such care. More generally, the question can be raised whether racial differences in use of prenatal testing reflect differences in culture (i.e., values and belief systems) between Whites and African-Americans, or whether such differences instead reflect differences in social structure (i.e., the differential location of members of the two groups in hierarchies of wealth, prestige, and power).

Some arguments that have been made for the role of values and belief systems cite the greater religiosity of African-Amer-

Survey Research Center, University of Michigan, Ann Arbor, MI 48106. 
icans, as well as their greater distrust of social institutions, as factors militating against their use of genetic technology (Citrin et al., 2001). Earlier studies of abortion attitudes, for example, have noted that African-American women were generally less supportive of legalized abortion than White women (Combs and Welch, 1982; Hall and Ferree, 1986), even though they are more than twice as likely to undergo abortions (Wilcox, 1990; www.cdc.gov). Others have cited concerns on the part of minorities that genetic testing might be used to justify increased racial and ethnic discrimination (Nelkin and Tancredi, 1989; Nelkin and Lindee, 1995; Citrin et al., 2001).

Over and against these arguments, however, is evidence that African-Americans have lower incomes, higher unemployment, and less access to health insurance and medical care than Whites (see Williams, 2002, esp. p. 593, and the references cited therein). The fact that they are less likely to make use of diagnostic and preventive health care may, therefore, be due less to their "distrust of the system" than to their inability to gain access to it.

The present study was designed to shed light on this issue. Although many scattered survey questions have been asked about various aspects of genetics and genetic testing (for a summary, see Singer et al., 1998), very few comprehensive studies have focused on this issue (but see Singer, 1991; Croyle and Lerman, 1993; Andrykowski et al., 1996, 1997; Wertz, 1997; Singer et al., 1999), and none have had large enough samples of ethnic or racial minorities to permit separate analyses of these groups. Accordingly, we decided to include enough AfricanAmericans as well as Latinos, who are a large and rapidly growing ethnic group in the United States, to permit separate analyses of their responses as well as comparisons between them and non-Hispanic White respondents. We did not, however, attempt to sample different subgroups of the Latino population. Note that in $2000,35.3$ million of 281.4 million (12.5\%) U.S. residents identified themselves as Spanish/Hispanic/Latino. Mexicans made up $7.3 \%$ of the population; Puerto Ricans, $1.2 \%$; Cubans, 0.4\%; other Hispanics, 3.6\%. An additional 3.8 million residents were enumerated in Puerto Rico. The Hispanic population increased by $57.9 \%$ since 1990 , compared with an increase of $13.2 \%$ for the total U.S. population (see http://www.census.gov/prod/2001pubs/c2kbr01-3.pdf).

This study provides information about the beliefs of AfricanAmericans, non-Hispanic Whites (hereafter, Whites), and Latinos with respect to both prenatal and adult genetic testing. The paper compares the three ethnic-racial groups with respect to (1) their beliefs and values about genetic technology and (2) potential barriers to testing. If there are, in fact, no differences in key elements of these beliefs, the argument that it is culture rather than structure that determines differential use of genetic technology loses much of its force. Such a finding would not prove that differential access, rather than different values and beliefs, determines actual use of genetic testing, but it would call the explanation in terms of different values and beliefs into question.

\section{METHODS}

From April 21 through November 26, 2000, the University of Maryland Survey Research Center (SRC) surveyed repre- sentative samples of three U.S. populations: the national population of all adults 18 or older residing in telephone households; the adult Latino population in telephone households; and the adult African-American population in telephone households. All three samples were obtained using a two-stage sample design. The first stage used a list-assisted Plus One Random-Digit Dial (RDD) frame for household selection. In each selected household, respondents were then randomly chosen using a household roster. For the Latino sample, the RDD frame was stratified to heavily sample states known to include most $(70 \%)$ of the Latino population (Texas, California, Florida, and New York). For both the Latino and the African-American samples, numbers were proportionately stratified by exchange, based on the estimated percentage of numbers in the exchange belonging to the target group. (A total of 4378 telephone numbers was released; 1795 were known to be non-households; for 344 , household status was unknown. The response rate calculated by American Association for Public Opinion Research (AAPOR) standards, which assume that a proportion of unknown telephone numbers are households, is $51-52 \%$.)

Prior to data collection, each household in the general population sample for which an address could be obtained was sent an advance letter describing the survey and eliciting cooperation; a $\$ 5$ incentive was included with each letter. If a respondent refused, another letter, but no additional incentive, was mailed to households that had received an advance letter. Late in the study, households that refused and had not received an advance letter or incentive were offered $\$ 10$ for their cooperation. Because the advance incentive procedure would have been inefficient with the Latino and African-American samples (since many households would have been screened out as ineligible), we offered all refusing households in these samples an incentive of $\$ 10$.

For the general population sample, we obtained 1232 interviews; the SRC standard response rate (which assumes all telephone numbers of unknown household status after 20 attempts to be non-households) is 55\%. For the Latino sample, 321 interviews were obtained, for a cooperation rate of $76 \%$; and for the African-American sample, 273 interviews were obtained, for a cooperation rate of $83 \%$. (Because most of the nonresponse in these samples is attributable to inability to contact the household to screen for eligibility, the AAPOR response rate for the Latino sample is only $28 \%$ and for the African-American sample, $45 \%$.) For the analyses reported in this paper, respondents in the two special samples were combined with Latino and African-American respondents in the national sample to create four non-overlapping groups consisting of 428 Latinos, 375 African-Americans, 960 non-Hispanic Whites, and 48 respondents who identified themselves as "other" race. (Results for this group are not shown in the analyses reported here.) Respondents who identified themselves as both black and Hispanic were classified as Hispanic; there were 41 such respondents. Unweighted data were used in the analyses for this paper.

The interview, averaging $26.6 \mathrm{~min}$, replicated questions that had been asked on a survey of public attitudes toward genetics carried out by Singer in 1990 (Singer, 1991, 1993), and added others appropriate to scientific developments and policy issues that had come to the fore since then. Where possible, we re- 
peated questions that had been used in earlier surveys (Singer et al., 1998). We also, however, relied on two kinds of exploratory work to make sure that questions were relevant to, and comprehended by, Latino and African-American respondents. In the first place, Singer and Antonucci participated as co-investigators in a study of attitudes toward genetic testing among members of African-American and Latino community groups in Michigan (Citrin et al., 2001; Singer et al., 2001). Some of the issues asked about in the present study-for example, the statements concerning possible misuse of genetic information-are directly derived from discussions in these groups. Second, the questionnaire was tested by means of cognitive interviews with 15 African-American and Latino respondents and revised several times to improve its comprehensibility. All questions used in the analysis are quoted in full either in the text or in a footnote.

We also prepared a Spanish-language version of the questionnaire. The Spanish-language version was prepared by a translator at the Gallup Organization and checked through backtranslation by a bilingual interviewer at the University of Michigan Survey Research Center. Almost half of the respondents who identified themselves as Hispanic were interviewed in the Spanish-language version of the questionnaire. For 185 respondents, the interview was conducted entirely in Spanish; for 15 others, it was conducted partly in Spanish and partly in English. The Spanish-language version of the questionnaire was offered to respondents at the discretion of the interviewer. If no bilingual interviewer was immediately available, the case was set aside for later recontact.

About half of the interviewers on the study were AfricanAmerican, but we did not attempt to match respondents and interviewers by race.

The tables below show responses for each of the three race/ethnic groups to each question analyzed. Also shown for each question is the significance of the difference between the responses of White respondents and African-American respondents and between Whites and Latinos. These significance levels reflect controls for education, age, language of interview, gender, marital status, having children, religion, and frequency of religious attendance in addition to race and ethnicity. For simplicity, these control variables are not shown in the tables, but discussions of significant differences in the text are based on regression equations that include these control variables. Analyses are based on either logistic or least-squares regression depending on whether the dependent variable is dichotomous or continuous. (When the dependent variable is a frequency count, we also estimated Poisson regressions. The results do not change in any significant way when this is done.) For most Yes-No and Agree-Disagree questions, one response category is modeled against all others, including Don't Know and Refused. For questions where the dependent variable is an ordered response scale, ordered logit models were run.

\section{BELIEFS AND VALUES WITH RESPECT TO GENETIC TESTING}

In this section, we discuss beliefs and values about genetic technology under the following headings: Preferences for prenatal testing and abortion; preferences for genetic testing for adults; and beliefs and attitudes about other aspects of genetic testing.

\section{Preferences for prenatal testing and abortion}

All respondents, whether they were male or female and whether or not they were of childbearing age, were asked about their preferences for prenatal testing. This question came after a series of others that defined genetic testing, asked about general attitudes toward testing, and measured the accuracy of respondents' knowledge about testing; these questions are discussed later in the paper. The question about prenatal testing read as follows, with wording varied depending on whether the respondent was a man or a woman:

Today, prenatal tests are being developed that make it possible to detect many serious genetic defects before a baby is born, but so far it is impossible to treat or correct most of them. These next questions are about prenatal genetic tests, that is, tests during pregnancy for genetic defects in the baby. If [you/your partner] were pregnant, would [you want/you want your partner] to have a test to find out if the baby has any serious genetic defects?

Almost two-thirds of the national sample (66.2\%) said they would want a prenatal genetic test if they or their partner were pregnant, a slight increase, from $63.6 \%(p<0.05)$, since the last time this question had been asked, in 1996 (Singer et al., 1999). White respondents were significantly less likely to express a preference for prenatal testing than either African-American or Latino respondents, even with other demographic characteristics held constant (see Table 1). There is, thus, no indication in the present study that Latinos and African-Americans are less likely to want prenatal testing than Whites.

In data not shown in Table 1, only $59.3 \%$ of White respondents and $34.3 \%$ of Latino respondents expressed a preference for prenatal testing for cystic fibrosis, a disease primarily affecting Whites. But more than three-quarters $(78.1 \%)$ of African-Americans said they would want prenatal testing for sickle cell anemia, a disease primarily of African-Americans, compared with only $37.1 \%$ of Latino respondents. (Whites were not asked about sickle cell anemia, and African-Americans were not asked about cystic fibrosis.)

These findings suggest that a desire for prenatal testing for sickle cell anemia may be one reason that African-Americans are more likely to express a preference for prenatal testing than Whites. (We had informed respondents early in the questionnaire that "Sickle cell anemia is a genetic blood disease that affects primarily African-Americans.") But they also indicate that preferences for prenatal testing vary depending on how the question is framed. In the abstract, about two-thirds of all respondents say they would want prenatal testing. But depending on what disease is specified, these percentages can be drastically reduced or sharply increased.

Respondents who said they themselves would want a prenatal test for either cystic fibrosis or sickle cell anemia were then asked, "Do you think all women who are expecting a baby have a responsibility to get such a prenatal genetic test, or don't you think so?" Of Whites who themselves wanted a test for cystic fibrosis, only a minority (40.9\%) thought all women should be 
Table 1. Attitudes Toward Prenatal Testing and Abortion, by Racial/Ethnic Identification

\begin{tabular}{|c|c|c|c|c|c|}
\hline Attitude & $\begin{array}{l}\text { African-American } \\
\qquad(\mathrm{n}=375)\end{array}$ & $\begin{array}{c}\text { Latino }^{\mathrm{a}} \\
(\mathrm{n}=428)\end{array}$ & $\begin{array}{c}\text { White } \mathrm{a}^{\mathrm{a}} \\
(\mathrm{n}=960)\end{array}$ & $\begin{array}{c}\mathrm{p} \text { Value } \\
\text { African-American } \\
\text { vs. White }\end{array}$ & $\begin{array}{l}\mathrm{p} \text { Value } \\
\text { Latino } \\
\text { vs. White }\end{array}$ \\
\hline Want prenatal test & $76.3 \%$ & $73.8 \%$ & $65.5 \%$ & $<0.01$ & $<0.05$ \\
\hline $\begin{array}{l}\text { Want abortion/ } \\
\text { end pregnancy }\end{array}$ & $23.3 \%$ & $27.0 \%$ & $23.0 \%$ & $<0.05$ & $<0.05$ \\
\hline $\begin{array}{l}\text { Abortion Index } \\
\text { (Mean \# of conditions for } \\
\text { which respondent would } \\
\text { want to end pregnancy) }\end{array}$ & 0.95 & 0.99 & 0.87 & $<0.01$ & $<0.10$ \\
\hline $\begin{array}{l}\text { Believes testing for height, } \\
\text { weight and hair color would } \\
\text { do more harm than good }\end{array}$ & $72 \%$ & $60 \%$ & $80.6 \%$ & $<0.05$ & $<0.10$ \\
\hline $\begin{array}{l}\text { Believes testing for } \\
\text { homosexuality would do } \\
\text { more harm than good }\end{array}$ & $60.3 \%$ & $49.2 \%$ & $75.5 \%$ & $<0.01$ & $<0.01$ \\
\hline $\begin{array}{l}\text { Believes testing for } \\
\text { criminality would do more } \\
\text { harm than good }\end{array}$ & $49.2 \%$ & $37.4 \%$ & $59.2 \%$ & $<0.10$ & $<0.05$ \\
\hline $\begin{array}{l}\text { Believes testing for shyness } \\
\text { would do more harm than good }\end{array}$ & $49.2 \%$ & $43.6 \%$ & $58.9 \%$ & $<0.05$ & $<0.10$ \\
\hline
\end{tabular}

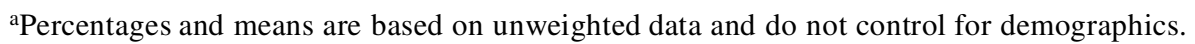

${ }^{\mathrm{b}} p$ values are based on multiple regressions that control for other variables and reflect two-sided tests of significance.

tested, compared with $68 \%$ of Latinos; among African-Americans and Latinos who wanted to be tested for sickle cell anemia, $66.2 \%$ and $74.2 \%$, respectively, felt all women had a responsibility to do so. Differences between Whites and the other two groups are statistically significant, even with other demographic characteristics controlled. This finding, like others to be reviewed later, suggests that both Latino and African-American respondents may feel a greater obligation toward others than White respondents, who tend to be more individualistic in their outlook.

Differences by race in preference for prenatal testing are reflected in preferences for abortion in case of serious fetal defect. We asked about abortion in two ways, using the word "abortion" in one version of the question and referring to it as "ending the pregnancy" in the other. The latter question asked:

Suppose the prenatal test shows the baby has a serious genetic defect. Would [you want/you want your partner] to end the pregnancy if a test shows the baby has a serious genetic defect?

Between $21 \%$ and $25 \%$ of respondents, depending on race/ethnicity, opted for "abortion," and between $24 \%$ and $29 \%$, again depending on race/ethnicity, opted for "ending the pregnancy." Neither the effect of form, nor the interaction between race and form, was significant, and we therefore combined the responses to the two versions of the question. As can be seen from Table 1, when other variables are controlled, White respondents are significantly less likely than African-American respondents and Latino respondents to say they would want an abortion under these circumstances.
In addition to asking about abortion in case of "serious genetic defect" we also asked:

If a prenatal genetic test showed a high chance of the following, for which situations, if any, would you consider ending the pregnancy?

Only "ending the pregnancy" was asked about. The following six hypothetical situations were asked about: The child would die before the age of 5 ; the child would be severely mentally retarded; the child would develop a disease causing death as a young adult; the child would suffer from depression; the child would be homosexual; the child would not be the sex you had hoped for. Half the sample was asked the questions in this order, and half in the reverse order; the effect of question order was not significant, and we therefore combined responses to the two versions of the question. Respondents who had indicated, in response to the earlier question about abortion/ending the pregnancy that they would not consider abortion under any circumstances were not asked these questions; there were 130 such respondents.

The mean number of situations for which respondents would consider an abortion was 0.87 among Whites, 0.95 among African-Americans, and 0.99 among Latinos; differences between Whites and African-Americans were significant and those between Latinos and Whites were marginally significant. Thus, White respondents in the present study were less likely than either Latino or African-American respondents to express a preference for both prenatal testing and abortion.

The condition for which the largest proportion of the sample $(33.7 \%)$ would choose to end the pregnancy was mental re- 
tardation, which was also the condition most respondents mentioned, in response to an open-ended question, when asked to identify the "serious defect" they had in mind in connection with a prenatal test. However, as many as $4.2 \%$ said they would end the pregnancy if the child were to be homosexual, and $2.1 \%$ said they would end the pregnancy if the child were not the sex they had hoped for.

We also asked respondents' opinion about genetic tests for things like height, weight, and hair color, considered by some as a potential misuse of genetic testing. Respondents were asked whether they thought such tests would do more good than harm, or more harm than good. Overwhelmingly, some three-quarters of the sample thought such tests would do more harm than good, but White respondents were significantly more likely to consider such tests harmful than African-American respondents and marginally more likely to do so than Latino respondents. They were also significantly more likely to believe that tests for homosexuality, criminality, and shyness would do more harm than good. Thus, although African-American and Latino participants in the Michigan discussion groups were very sensitive to eugenic implications of genetic testing (Citrin et al., 2001), the current national survey indicates that under certain circumstances White respondents are even more sensitive to such considerations.

To clarify these responses, a random subsample of respondents was asked the reason for their answer. Among the most common reasons given for considering the tests harmful was a belief that they would lead to eugenic selection (36\% of the responses) and a statement that genetic tests should be done only for health reasons $(9 \%)$, or that they were not needed $(26 \%)$. Other reasons made reference to God, religion, morals, or ethics $(9 \%)$, or to leaving things to nature or chance $(9 \%)$. The main reason given for judging such tests as useful rather than harmful was because they could provide information helpful in planning ahead (74\%). There were no differences in these openended responses by race or ethnicity, but the questions were asked of small numbers of respondents only.

\section{Preferences for genetic tests for adults}

An increasing number of genetic tests can be used to predict the likelihood that an adult individual will develop a particular disease. (As of May, 2002, there were genetic tests for over 900 inherited conditions, 556 of them available on a clinical basis; 323 of those were offered as prenatal tests, and the number of such tests is growing; Genetests.Geneclinics Genetics Information Resource. Copyright, University of Washington and Children's Health Care System, Seattle, 1995. Available at http://www.genetests.org or http://www.geneclinics.org, accessed on May 23, 2002.) Some of these diseases, such as breast and colon cancer, are not invariably fatal and an early test may allow the person to take preventive action; others, such as Huntington disease, are invariably fatal, but an early test may permit the affected individual to engage in advance planning.

Both types of tests carry certain risks having nothing to do with the disease itself. For example, there may be implications for employment or insurability if the results become known to one's employer or insurance company (e.g., Canter, 1984; Draper, 1986, 1991; Uzych, 1986; Holtzman, 1989; Billings et al., 1992; Institute of Medicine, 1994). And if the test results are shared, they may confer unwanted knowledge on siblings or other family members.

Preferences for genetic testing among adults have been evaluated only infrequently. However, Andrykowski et al. (1997) note that $82 \%$ of Kentucky residents interviewed by telephone in 1995 said that they would undergo a blood test for cancer if it was inexpensive and easy to perform, and in a similar survey of Kentucky residents a year earlier, Andrykowski and colleagues (1996) found that $87 \%$ expressed an interest in learning about a genetic predisposition to cancer in general, and $93 \%$ for learning about breast cancer in particular. A telephone survey by Croyle and Lerman (1993) of Utah residents in 1990 found that $83 \%$ expressed an interest in genetic testing for colon cancer. A Canadian survey carried out in Ontario at about the same time, however, found a much smaller proportion, $39.9 \%$, expressing such an interest. That proportion was further reduced when a number of qualifying conditions were introduced in subsequent questions (Graham et al., 1998).

Reviewing questions asked on national surveys of the general population, Singer et al. (1998, p. 636 and Tables 17 and 18 ) report that "the vast majority . . . would take a genetic test capable of detecting a curable disease, and somewhat smaller majorities say they would take such a test even if there were no cure. Both percentages seem to be increasing over time."

In the present survey, we asked similar questions about tests for treatable and for fatal illnesses, phrasing each both in a specific and a more abstract version. The following questions were asked about a treatable illness: "If a genetic test could tell you whether or not you are likely to get a treatable genetic disease later in life, would you personally want such a test or not?" or "Colon cancer is a disease that can be treated. There is a simple blood test for some of the genetic changes that increase the chance of getting colon cancer. Would you personally want to have such a test, or not?" A random half of the sample was asked each version of the question. The questions about tests for an untreatable illness were as follows: "Some genetic diseases are not treatable. If a genetic test could tell you whether or not you will develop a serious, disabling disease later in life for which there is no treatment or cure at present, would you personally want to have such a test or not?" or "Some genetic diseases are not treatable. Huntington disease is a progressive, disabling genetic disease that usually develops when people are in their forties. It affects the brain and cannot be treated or cured. Would you personally want to have such a test or not?"

Among Latino respondents, $76.5 \%$ said they would want to be tested for a "treatable genetic disease" (see Table 2). This is a higher percentage than either African-American or White respondents, but the differences are reduced to insignificance when other demographic characteristics are controlled. When the question is asked about colon cancer, a specific treatable genetic disease, more than $80 \%$ of each of the three groups profess a desire to undergo testing, and again there are no significant differences by race/ethnicity.

The proportions expressing a desire to be tested for a disease for which no treatment or cure is available are, not unexpectedly, much lower. Some $58 \%$ of African-American respondents and $61 \%$ of Latino respondents say they would want to be tested for an untreatable illness, but only $43 \%$ of White respondents-differences that are statistically significant even with other demographic characteristics controlled. The same 
Table 2. Attitude Toward Genetic Testing for Adults, by Racial/Ethnic Identification

\begin{tabular}{|c|c|c|c|c|c|}
\hline Attitude & $\begin{array}{l}\text { African-American } \\
\qquad(\mathrm{n}=375)\end{array}$ & $\begin{array}{c}\text { Latino }^{\mathrm{a}} \\
(\mathrm{n}=428)\end{array}$ & $\begin{array}{c}\text { White }^{\mathrm{a}} \\
(\mathrm{n}=960)\end{array}$ & $\begin{array}{c}\mathrm{p} \text { Value } \\
\text { African-American } \\
\text { vs. White }\end{array}$ & $\begin{array}{c}\mathrm{p} \text { Value } \\
\text { Latino } \\
\text { vs. White }\end{array}$ \\
\hline Want test for treatable disease & $64.8 \%$ & $76.5 \%$ & $64.7 \%$ & $\mathrm{NS}^{\mathrm{c}}$ & $\mathrm{NS}^{\mathrm{c}}$ \\
\hline Want test for colon cancer & $83.9 \%$ & $81.2 \%$ & $80.8 \%$ & $\mathrm{NS}^{\mathrm{c}}$ & $\mathrm{NS}^{\mathrm{c}}$ \\
\hline Want test for untreatable disease & $57.6 \%$ & $61.3 \%$ & $42.6 \%$ & $<0.01$ & $<0.10$ \\
\hline Want test for Huntington Disease & $56.4 \%$ & $60.2 \%$ & $43.8 \%$ & $<0.05$ & $<0.01$ \\
\hline
\end{tabular}

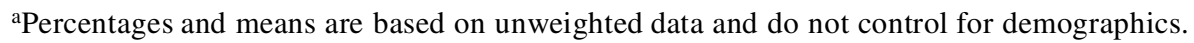

${ }^{\mathrm{b}} p$ values are based on multiple regressions that control for other variables and reflect two-sided tests of significance.

${ }^{\mathrm{c}} \mathrm{NS}$, Not significant.

pattern holds when the question is asked about Huntington, a specific untreatable disease. Thus, once again, there is no indication that African-American or Latino respondents are less likely to want genetic testing than White respondents.

\section{Beliefs and attitudes with respect to other aspects of genetic testing}

We asked two questions about the use of deoxyribonucleic acid (DNA). The first was designed to probe beliefs about the relative accuracy of fingerprint and DNA evidence for purposes of identification. Although the media have publicized many cases in which convicted criminals have been freed on the basis of DNA evidence, the practice of collecting DNA from suspects and storing it for future use has also aroused protests, especially among African-Americans.

There were significant differences between White and African-American respondents in their evaluation of the use of DNA evidence compared with fingerprints, with White respondents rating it as better. Differences between White and Latino respondents were not significant with other demographic variables controlled (see Table 3).

The second question asked about proposals to collect a sample of DNA from each newborn and store it in a data bank for subsequent use in criminal investigations as well as medical re- search. The question deliberately included a reference to benefits (medical research) as well as possible costs (criminal investigations), requiring respondents to balance them when evaluating the proposal. With other demographic characteristics included as controls, there were no significant differences between White respondents and either of the other two race/ethnic groups.

\section{Cloning}

Respondents were also asked several questions about cloning, a process in which genetic material from one individual is implanted into an unfertilized egg, resulting in the development of an embryo which is a duplicate, or clone, of the individual. At present, the cloning of animals is permitted by law, and a ban on human cloning that passed the House of Representatives in 2001 has so far been blocked in the Senate (as of early 2004).

The first series of questions defined cloning and then asked whether the respondent believed cloning animals should be allowed to continue or not; those who thought it should not be allowed to continue were asked whether the ban should be temporary or permanent, and whether they were opposed to cloning for religious or moral, or for other, reasons.

African-American respondents were significantly more

Table 3. Attitude Toward Other Aspects of Genetic Testing by Racial/Ethnic Identification

\begin{tabular}{|c|c|c|c|c|c|}
\hline Attitude & $\begin{array}{l}\text { African-American }{ }^{\mathrm{a}} \\
\quad(\mathrm{n}=375)\end{array}$ & $\begin{array}{l}\text { Latino }^{\mathrm{a}} \\
(\mathrm{n}=428)\end{array}$ & $\begin{array}{c}\text { White } \\
(\mathrm{n}=960)\end{array}$ & $\begin{array}{c}\mathrm{p} \text { Value } \\
\text { African-American } \\
\text { vs. White }\end{array}$ & $\begin{array}{l}\mathrm{p} \text { Value } \\
\text { Latino } \\
\text { vs. White }\end{array}$ \\
\hline DNA better than fingerprints & $48.3 \%$ & $58.3 \%$ & $70.2 \%$ & $<0.01$ & $\mathrm{NS}^{\mathrm{c}}$ \\
\hline $\begin{array}{l}\text { How acceptable is it to store DNA? } \\
\text { (Very acceptable) }\end{array}$ & $20.3 \%$ & $26.0 \%$ & $24.0 \%$ & $N S^{c, d}$ & $\mathrm{NS}^{\mathrm{c}, \mathrm{d}}$ \\
\hline $\begin{array}{l}\text { Should research on animal cloning } \\
\text { be allowed to continue? } \\
\text { (Yes) }\end{array}$ & $23.7 \%$ & $38.6 \%$ & $45.8 \%$ & $<0.01$ & $\mathrm{NS}^{\mathrm{c}}$ \\
\hline $\begin{array}{l}\text { Should research on human cloning } \\
\text { be allowed to continue? } \\
\text { (Yes) }\end{array}$ & $16.3 \%$ & $22.9 \%$ & $19.2 \%$ & $\mathrm{NS}^{\mathrm{c}}$ & $\mathrm{NS}^{\mathrm{c}}$ \\
\hline
\end{tabular}

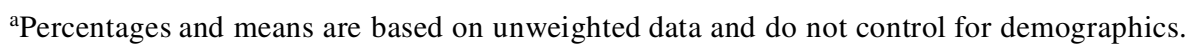

${ }^{\mathrm{b}} p$ values are based on multiple regressions that control for other variables and reflect two-sided tests of significance.

${ }^{\mathrm{c} N S}$, Not significant.

${ }^{\mathrm{d}}$ These equations treat the dependent variable as an ordered logit. 
likely to be opposed to cloning animals than either Latino or White respondents. Only $23.7 \%$ of the African-American sample thought experiments on animal cloning should continue, compared with $38.6 \%$ of the Latino and $45.8 \%$ of the White sample. African-American respondents were significantly more likely to cite religious and moral reasons for opposing continued cloning of animals than they were to cite other reasons.

When the same questions were asked about the cloning of human embryos, the proportion opposed to continued research increased significantly, with about $80 \%$ of all three race/ethnic groups expressing opposition. Differences among the three groups were not significant. Moral and religious reasons were cited significantly more often than other reasons by those opposed to continued research in this area. Thus, unlike preferences for prenatal and adult genetic testing, attitudes toward other aspects of genetic testing show either no differences by race or ethnicity or reveal more favorable attitudes among Whites than among either of the other groups.

\section{Potential barriers to testing}

So far, we have examined preferences for prenatal and adult genetic testing and for abortion in the case of a serious genetic fetal defect, as well as attitudes toward other aspects of genetic testing. Such differences as were found among the three race/ethnic groups generally indicated a greater preference for prenatal and adult genetic testing among nonwhite respondents. In this section, we examine what we call potential barriers to testing, in an effort to account for the fact that although Latinos and African-Americans express a greater preference for testing, they appear to avail themselves of testing less often than Whites. The following barriers are considered: Information about genetic testing; knowledge and interest; insurance coverage; concerns about the possible misuse of genetic testing; concerns about privacy; and confidentiality and trust.

\section{Information about genetic testing}

Sources of Information: One potential barrier to the use of genetic testing is simply lack of accurate information about what tests are available. The interview began with several general information questions. These asked how closely the respondent followed news about science and health, and which sources of information were used for getting such news. Respondents interviewed in Spanish were significantly less likely to follow such news than those interviewed in English, a fact that may have a bearing on their attitudes. We return to this in the discussion section.

All those who reported more than minimal exposure to news about science and health were asked whether or not they used each of the following sources: television, radio, newspapers or magazines, the Internet, friends or family members, a religious group or organization, and their doctor. They were also asked which was the most important source for them. For all three race/ethnic groups, doctors were the most important source$37.9 \%$ of White respondents, $50 \%$ of African-American respondents, and $32.3 \%$ of Latino respondents named their doctor as the most important source (data not shown). For the latter two groups, however, television is the next most frequently cited most important source, by $31.9 \%$ of Latinos and $24.4 \%$ of African-Americans, respectively; for White respondents, newspapers and magazines, named by $30.4 \%$, are second in importance to their doctor. The other sources were cited as most important by very small percentages of each of the three groups.

Knowledge and interest. A series of seven factual questions assessed respondents' knowledge about genetic testing. These were asked very early in the interview, before any other questions that might inadvertently provide respondents with cues to the correct answers. These questions were: "As far as you know, is each of the following statements about the uses of genetic testing true or false, or are you not sure? Genetic testing can be used in adults to find out if they have a greater than average chance of developing certain kinds of cancer (T); Genetic testing can be used in adults to find out if they have a greater than average chance of developing depression (F); Genetic testing can be used in adults to predict whether a person will have a heart attack (F); Genetic testing can be used during pregnancy to find out whether the baby will develop sickle cell disease or cystic fibrosis (T); Gene therapy is currently being used to correct many of the defects found through genetic testing $(\mathrm{F})$; Sickle cell anemia is a genetic blood disease that affects mainly African-Americans. As far as you know, is there a cure for sickle cell anemia? (No); Cystic fibrosis is a genetic disease that may lead to serious problems with breathing and digestion. As far as you know, is there a cure for cystic fibrosis? (No)"

Respondents answered less than half the questions correctly, on average, and there were significant differences among the three race/ethnic groups, with White respondents answering significantly more questions correctly than either of the other groups. On an index omitting the two questions about cures for specific diseases, only the differences between African-American and White respondents remained significant (see Table 4).

After the conclusion of the interview, interviewers were asked to rate respondents' interest in, and understanding of, the survey topic. White respondents were rated as significantly more interested than African-American respondents, as well as having a significantly better understanding. Thus, there is some support for the possibility that lack of information may constitute one barrier to utilization of genetic testing on the part of African-American respondents.

Respondents who identified themselves as Latino and who were interviewed in Spanish were significantly less accurate with respect to the genetic knowledge questions than those interviewed in English, and they were also rated by interviewers as significantly less likely to have an understanding of the topic than those interviewed in English. We return to the implications of this in the discussion section.

\section{Insurance coverage of genetic testing}

Another potential barrier to testing on the part of AfricanAmerican and Latino respondents is lack of insurance coverage for such tests. At present, there is considerable variability in insurance companies' coverage for genetic testing, and the conditions under which coverage applies may also be ambiguous. Medicare does not cover basic genetic testing. Medicaid covers newborn screening and a nominal number of other genetic tests dealing with cancer diagnosis. Many genetic tests, however, are not covered.

We asked respondents in our sample about the kind of health insurance they and their families had. As can be seen from Table 
Table 4. Knowledge, Interest, and Understanding about Genetic Testing, By Racial/Ethnic Identification

\begin{tabular}{|c|c|c|c|c|c|}
\hline $\begin{array}{l}\text { Knowledge, interest, and } \\
\text { understanding }\end{array}$ & $\begin{array}{l}\text { African-American }{ }^{\mathrm{a}} \\
\quad(\mathrm{n}=375)\end{array}$ & $\begin{array}{l}\text { Latino }^{\mathrm{a}} \\
(\mathrm{n}=428)\end{array}$ & $\begin{array}{c}\text { White } \mathrm{a}^{\mathrm{a}} \\
(\mathrm{n}=960)\end{array}$ & $\begin{array}{c}\mathrm{p} \text { Value } \\
\text { African-American } \\
\text { vs. White }\end{array}$ & $\begin{array}{c}\mathrm{p} \text { Value } \\
\text { Latino } \\
\text { vs. White }\end{array}$ \\
\hline $\begin{array}{l}\text { Follow news about science } \\
\text { very closely }\end{array}$ & $27.1 \%$ & $21.6 \%$ & $19.5 \%$ & $<0.10^{c}$ & $\mathrm{NS}^{\mathrm{c}, \mathrm{d}}$ \\
\hline $\begin{array}{l}\text { Knowledge index (seven items) } \\
\text { (Mean \# accurate) }\end{array}$ & 3.18 & 2.70 & 3.39 & $<0.05$ & $<0.01$ \\
\hline $\begin{array}{l}\text { Knowledge index (five items) } \\
\text { (Mean \# accurate) }\end{array}$ & 1.78 & 1.82 & 1.94 & $<0.05$ & $\mathrm{NS}^{\mathrm{d}}$ \\
\hline Very interested in survey topic & $41.1 \%$ & $45.8 \%$ & $52.2 \%$ & $<0.01^{\mathrm{c}}$ & $\mathrm{NS}^{\mathrm{c}, \mathrm{d}}$ \\
\hline Excellent understanding of survey topic & $35.7 \%$ & $35.1 \%$ & $45.5 \%$ & $<0.01$ & $\mathrm{NS}^{\mathrm{d}}$ \\
\hline
\end{tabular}

aPercentages and means are based on unweighted data and do not control for demographics.

${ }^{\mathrm{b}} p$ values are based on multiple regressions that control for other variables and reflect two-sided tests of significance.

${ }^{\mathrm{c}}$ These equations treat the dependent variable as an ordered logit.

${ }^{\mathrm{d}} \mathrm{NS}$, Not significant.

5, approximately $30 \%$ of the three groups were covered by Medicare. A smaller proportion reported coverage by Medicaid, with African-Americans again significantly more often reporting such coverage. Some $85 \%$ of the White sample reported access to private health insurance, a significantly higher proportion than either the African-American or the Latino sample. In general, minority populations are more likely to be covered by Medicare or Medicaid, whereas White respondents are more likely to have private health insurance. Thus, there are financial as well as informational barriers to the utilization of genetic testing by Latino and African-American populations.

We asked all respondents whether they thought private health insurance plans should pay for prenatal genetic tests, and whether publicly funded programs such as Medicaid should pay for such tests. Not unexpectedly, groups more favorable toward prenatal testing were also more likely to believe that insurance, whether public or private, should cover the expense of such tests. White respondents, who were less likely to say they would want prenatal testing, were significantly less likely than either
Latino or African-American respondents to favor coverage of such tests by insurance companies. When we asked whether abortion in case of fetal defect should be covered by insurance, whether private or public, White respondents were again significantly less likely to favor such coverage than Latino or African-American respondents. Whether or not respondents themselves had any kind of insurance did not significantly affect their answer to the question about paying for abortion (with demographic variables controlled), but it did affect answers to the question about paying for prenatal testing. Those with insurance of some kind were significantly more likely to say that insurance should cover the costs of such tests (data not shown).

\section{Concerns about the possible misuse of genetic testing}

So far, we have considered informational and financial barriers to genetic testing. We turn next to some potential attitudinal barriers.

Early in the interview, respondents were asked several ques-

Table 5. Insurance Coverage and Attitudes by Racial/Ethnic Identification

\begin{tabular}{|c|c|c|c|c|c|}
\hline Coverage and attitudes & $\begin{array}{l}\text { African-American } \\
\quad(\mathrm{n}=375)\end{array}$ & $\begin{array}{c}\text { Latino }^{\mathrm{a}} \\
(\mathrm{n}=428)\end{array}$ & $\begin{array}{c}\text { White } \mathrm{a}^{\mathrm{a}} \\
(\mathrm{n}=960)\end{array}$ & $\begin{array}{c}\mathrm{p} \text { Value } \\
\text { African-American } \\
\text { vs. White }\end{array}$ & $\begin{array}{l}\mathrm{p} \text { Value } \\
\text { Latino } \\
\text { vs. White }\end{array}$ \\
\hline Has Medicare & $29.3 \%$ & $26.6 \%$ & $30.0 \%$ & $<0.01$ & $\mathrm{NS}^{\mathrm{c}}$ \\
\hline Has Medicaid & $21.1 \%$ & $13.8 \%$ & $8.4 \%$ & $<0.01$ & $\mathrm{NS}^{\mathrm{c}}$ \\
\hline Has private insurance & $70.1 \%$ & $61 \%$ & $85 \%$ & $<0.01$ & $<0.01$ \\
\hline Has any insurance & $89.7 \%$ & $80.3 \%$ & $93.4 \%$ & $\mathrm{NS}^{\mathrm{c}}$ & $\mathrm{NS}^{\mathrm{c}}$ \\
\hline $\begin{array}{l}\text { Should insurance pay for prenatal } \\
\text { genetic testing/counseling? } \\
\text { (Mean score on four-item index) }\end{array}$ & 3.47 & 3.37 & 3.00 & $<0.01$ & $<0.01$ \\
\hline $\begin{array}{l}\text { Should insurance pay for abortion? } \\
\text { (Mean score on two-item index) }\end{array}$ & 1.09 & 1.21 & 1.03 & $<0.01$ & $<0.01$ \\
\hline
\end{tabular}

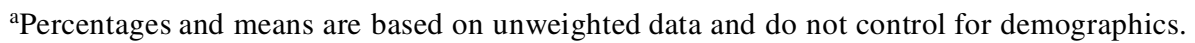

${ }^{\mathrm{b}} p$ values are based on multiple regressions that control for other variables and reflect two-sided tests of significance.

${ }^{\mathrm{c}} \mathrm{NS}$, Not significant. 
tions about their expectations for the future of genetic testing. Placement of these questions was designed to prevent later questions from influencing the responses. The first such question asked:

The next questions are about genes and genetic testing. Genes are the blueprint for how everything in the body works. Genetic testing makes it possible to tell whether or not someone is likely to develop certain diseases or conditions. Some people say genetic testing is a wonderful medical advance. Others think it may cause trouble. What about you-do you think genetic testing will do more good than harm, or more harm than good?

With other demographic variables controlled, Latinos were significantly more likely than Whites to believe that genetic testing would do more harm than good, and African-Americans were marginally more likely to do so (see Table 6). There is, thus, an indication that both Latino and African-American respondents have more reservations about the future of genetic testing than White respondents do.

An open-ended question probed the reasons for the respondent's belief that genetic tests would do more good than harm or more harm than good. The most common reasons for believing such tests would do more good than harm were expectations that they would lead to cures for, or prevention of, disease (39\%) or would provide useful knowledge (36\%); some respondents based their answer on past scientific advances or general faith in science and technology (7\%). The chief reasons for believing that genetic tests would bring more harm than good were reasons based on God, religion, or ethical beliefs, or the belief that one should let nature take its course (26\%). Other reasons involved the belief that such tests would lead to eugenic selection or discrimination $(15 \%)$ or cloning or other misuse $(20 \%)$.

Following these very general questions came eight statements designed to probe beliefs about the potential misuse of genetic testing. Respondents were asked whether they strongly agreed, somewhat agreed, somewhat disagreed, or strongly disagreed with each of the following statements, which were based on comments made in discussion groups composed entirely of African-American or Latino participants, conducted before the present survey was fielded (cf. Singer et al., 2001).

Genetic testing during pregnancy is a good thing because it allows people to choose to have the children they really want.
Genetic testing will lead to discrimination against people who are not perfect.

Anonymous genetic testing, where no record is kept of the person's name, should be available to people who want it.

Genetic testing will mostly benefit people who already have a lot of advantages.

Information from genetic tests is likely to be misused.

Genetic testing is the first step to getting rid of people the government considers undesirable.

Scientists are creating unrealistic hopes about how soon cures will be found for genetic diseases.

Research on genes is taking away money that should be used for other health problems

We created an Index of Negative Use that summed responses to these statements, with strong agreement scored 2, agreement 1 , and all other responses, 0 (scoring on the first and third items was reversed). Thus, high scores indicate very negative beliefs about the consequences of genetic testing, and low scores indicate the relative absence of such beliefs.

Scores on this index indicated that both African-American and Latino respondents had significantly more negative beliefs about the consequences of genetic testing than White respondents, and such beliefs, along with fewer informational and financial resources, may well counteract the greater preferences they express for both prenatal and adult genetic testing.

\section{Concerns about privacy and confidentiality}

Concerns about the confidentiality of test results, and about possible consequences of such breaches for employment and insurance, have been mentioned in connection with preferences for adult genetic testing, above. We asked a series of questions in this study that were relevant to such concerns. For each of the adult-onset diseases for which we asked whether the respondent would want to be tested, we also asked, "Suppose a test shows that a person will probably develop [it]. The next questions are about who you think has the right to know this information." In each case, we asked (1) about the person's spouse or life partner; (2) a fiancé or a future life partner; (3) other immediate family, like brothers and sisters; (4) the person's employer; and (5) the person's health insurance company. The belief that others who might be affected by one's propensity for illness had a right to genetic test results was measured by the sum of Yes responses to these questions.

Table 6. Concerns about Misuse by Racial/Ethnic Identification

\begin{tabular}{|c|c|c|c|c|c|}
\hline Concerns about misuse & $\begin{array}{l}\text { African-American } \\
\qquad(\mathrm{n}=375)\end{array}$ & $\begin{array}{l}\text { Latino }^{\mathrm{a}} \\
(\mathrm{n}=428)\end{array}$ & $\begin{array}{l}\text { White }{ }^{\mathrm{a}} \\
(\mathrm{n}=960)\end{array}$ & $\begin{array}{c}\mathrm{p} \text { Value } \\
\text { African-American } \\
\text { vs. White }\end{array}$ & $\begin{array}{c}\mathrm{p} \text { Value } \\
\text { Latino } \\
\text { vs. White }\end{array}$ \\
\hline $\begin{array}{l}\text { General attitude toward genetic testing } \\
\quad(\% \text { harm }>\text { good })\end{array}$ & $18.2 \%$ & $15.3 \%$ & $12.4 \%$ & $<0.10$ & $<0.05$ \\
\hline $\begin{array}{l}\text { "Negative Use" Index } \\
\text { (Mean score) }\end{array}$ & 6.34 & 5.89 & 4.96 & $<0.01$ & $<0.01$ \\
\hline
\end{tabular}

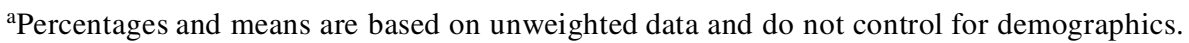

${ }^{\mathrm{b}} p$ values are based on multiple regressions that control for other variables and reflect two-sided tests of significance. 
Using this measure, White respondents were the most protective of privacy of the three race/ethnic groups, scoring consistently and significantly lower than either of the other two groups (see Table 7). Wertz (1998), reporting similar findings, has interpreted this as reflecting a greater sense of obligation toward friends and family members on the part of AfricanAmerican and Latino respondents. Therefore, we examined each of the items of the "right to know" index separately, reasoning that respondents might feel an obligation toward family members but not necessarily toward employers or insurance companies. However, for each item of the "right to know" index, African-American and Latino respondents were more likely than White respondents to say others had a right to know the results of testing. Thus, the interpretation of this pattern of responses is somewhat ambiguous and may reflect "yea-saying" rather than felt obligation toward friends and family members. The reasons for these differences in responses clearly need further research.

Certainly, with respect to other privacy-related attitudes, African-American and Latino respondents tend to express views that indicate greater concerns. The first question about privacy asked respondents whether they agreed strongly, somewhat, only a little, or not at all with the statement, "People's rights to privacy are well protected." Significantly more AfricanAmericans and Latinos expressed strong disagreement with this statement. African-Americans were significantly more likely to express strong agreement with the statement, "The government already knows more about me than it needs to" (there were no significant differences between Latinos and Whites). Finally, both African-American and Latino respondents were signifi- cantly more likely to say that their phone had ever been tapped. In short, African-American and Latino respondents give some evidence of being more concerned about personal privacy than White respondents, and these concerns may work against their seeking out both prenatal and adult genetic testing.

\section{Confidence and trust}

At the very end of the interview, respondents were asked how much confidence they had in the people running the government in Washington, the leaders of science, and the corporations that make and sell genetic tests. They were also asked how much they trusted their doctor to keep medical information about them private.

African-Americans are often assumed to be more distrustful of government and medical institutions than Anglo-Americans are, and indeed this is borne out in the current study. On an index combining responses to the three confidence questions, White respondents expressed significantly more confidence than African-American respondents did (see Table 8). They were also more likely to trust their doctor to keep information about them private. The responses of Latinos did not differ significantly from those of other Whites.

A similar pattern was observed on three other statements measuring efficacy and trust. The statements were the following: Most people can be trusted; people like me don't have any say about what the government does; I don't think public officials care much what people like me think. For each of these, respondents were asked to indicate whether they strongly agreed, somewhat agreed, somewhat disagreed, or strongly disagreed. On all of these,

Table 7. Concerns about Privacy by Racial/Ethnic Identification

\begin{tabular}{|c|c|c|c|c|c|}
\hline Concerns about privacy & $\begin{array}{l}\text { African-American } \\
\quad(\mathrm{n}=375)\end{array}$ & $\begin{array}{l}\text { Latino }^{\mathrm{a}} \\
(\mathrm{n}=428)\end{array}$ & $\begin{array}{c}\text { White } \mathrm{a}^{\mathrm{a}} \\
(\mathrm{n}=960)\end{array}$ & $\begin{array}{c}\mathrm{p} \text { Value } \\
\text { African-American } \\
\text { vs. White }\end{array}$ & $\begin{array}{l}\mathrm{p} \text { Value } \\
\text { Latino } \\
\text { vs. White }\end{array}$ \\
\hline $\begin{array}{l}\text { Who has the right to know results } \\
\text { of test for treatable illness? } \\
\text { (Mean score on five-item index) }\end{array}$ & 3.13 & 3.16 & 2.66 & $<0.01$ & $<0.10$ \\
\hline $\begin{array}{l}\text { Who has the right to know results } \\
\text { of test for colon cancer? } \\
\text { (Mean score on five-item index) }\end{array}$ & 3.41 & 3.28 & 2.66 & $<0.01$ & $<0.01$ \\
\hline $\begin{array}{l}\text { Who has the right to know results } \\
\text { of test for untreatable illness? } \\
\text { (Mean score on five-item index) }\end{array}$ & 3.18 & 3.16 & 2.48 & $<0.01$ & $<0.01$ \\
\hline $\begin{array}{l}\text { Who has right to know results of } \\
\text { test for Huntington Disease? } \\
\text { (Mean score on five-item index) }\end{array}$ & 3.44 & 3.23 & 2.69 & $<0.01$ & $<0.05$ \\
\hline $\begin{array}{l}\text { Privacy is well protected } \\
\text { (Strongly disagree) }\end{array}$ & $43.6 \%$ & $34.7 \%$ & $30.1 \%$ & $<0.01$ & $<0.10$ \\
\hline $\begin{array}{l}\text { Government knows too much } \\
\text { (Strongly agree) }\end{array}$ & $68.2 \%$ & $50.0 \%$ & $50.2 \%$ & $<0.01$ & NS \\
\hline Phone ever tapped? & $37.3 \%$ & $27.8 \%$ & $15.8 \%$ & $<0.01$ & $<0.01$ \\
\hline
\end{tabular}

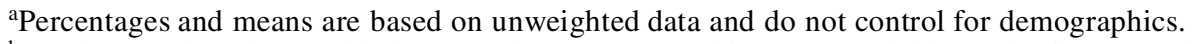

${ }^{\mathrm{b}} p$ values are based on multiple regressions that control for other variables and reflect two-sided tests of significance. 
Table 8. Confidentiality, Efficacy, and Trust by Racial/Ethnic Identification

\begin{tabular}{|c|c|c|c|c|c|}
\hline $\begin{array}{l}\text { Confidentiality, } \\
\text { efficacy, and trust }\end{array}$ & $\begin{array}{c}\text { African-Americant } \\
(\mathrm{n}=375)\end{array}$ & $\begin{array}{c}\text { Latino }^{\mathrm{a}} \\
(\mathrm{n}=428)\end{array}$ & $\begin{array}{c}\text { White }^{\mathrm{a}} \\
(\mathrm{n}=960)\end{array}$ & $\begin{array}{c}\mathrm{p} \text { Value } \\
\text { African-American } \\
\text { vs. White }\end{array}$ & $\begin{array}{l}\mathrm{p} \text { Value } \\
\text { Latino } \\
\text { vs. White }\end{array}$ \\
\hline $\begin{array}{l}\text { Confidence in institutions } \\
\text { (Mean score on three-item index) } \\
\text { (Low = less confidence) }\end{array}$ & 1.99 & 2.04 & 2.41 & $<0.01$ & $\mathrm{NS}^{\mathrm{c}}$ \\
\hline $\begin{array}{l}\text { Trust your MD to keep information } \\
\text { about you private } \\
\text { (A great deal) }\end{array}$ & $50.9 \%$ & $48.2 \%$ & $59.1 \%$ & $<0.01$ & $\mathrm{NS}^{\mathrm{c}}$ \\
\hline Trust people (strongly disagree) & $32.3 \%$ & $34.4 \%$ & $12.7 \%$ & $<0.01$ & $<0.01$ \\
\hline $\begin{array}{l}\text { Efficacy (two item index; lower score } \\
\text { means more efficacy) }\end{array}$ & 0.79 & 0.65 & 0.56 & $<0.01$ & $\mathrm{NS}^{\mathrm{c}}$ \\
\hline
\end{tabular}

aPercentages and means are based on unweighted data and do not control for demographics.

${ }^{\mathrm{b}} p$ values are based on multiple regressions that control for other variables and reflect two-sided tests of significance.

${ }^{\mathrm{c}} \mathrm{NS}$, Not significant.

African-American respondents indicated significantly less efficacy and trust than White respondents, whereas Latino respondents did not differ significantly from Whites on three of the four.

It has been hypothesized that absence of trust in American institutions is what leads African-Americans to have more negative attitudes toward genetic testing than Whites. We tested this hypothesized mediating role of confidence in societal institutions on the relationship between race and a number of the dependent variables that reveal more negative attitudes on the part of African-Americans, including expectations about the future of genetic testing, the negative use index, and approval of animal cloning. Adding scores on the confidence index to the other predictor variables eliminated the significant difference between Whites and African-Americans on expectations about the future of genetic testing, but it did not eliminate such differences on either of the other variables. Clearly, confidence in institutions does not in itself explain the more negative responses of African-Americans to these items.

\section{DISCUSSION AND CONCLUSIONS}

It is clear from our study that African-American and Latino respondents are, if anything, more eager to avail themselves of genetic testing, whether prenatal or adult, than White respondents are. Their apparently lower utilization of this technology cannot, therefore, be attributed to negative attitudes toward testing itself. At the same time, African-Americans and Latinos have lower average income than Whites, and are less likely to carry private health insurance. Thus, their ability to avail themselves of genetic testing is reduced relative to Whites.

In addition, however, African-Americas, in particular, share a number of beliefs that may conflict with their desire for genetic testing and discourage their use of it. They are less knowledgeable about what such tests can and cannot do, they are more concerned about privacy vis-à-vis the government, and they are more concerned about the possible misuses of genetic information. They express less confidence in American institutions and less trust in their doctor and in people in general, and less of a sense of political efficacy. These attitudes may well override their desire for genetic testing in any given situation.

It has been suggested that their greater lack of confidence in American institutions is responsible for some of the differences between the responses of African-American and White respondents on this survey. As we have seen, this appears to be true for expectations about whether such testing will do more good than harm in the future, but not for concerns about possible misuses of genetic information, as measured by the Negative Use Index.

With respect to these attitudinal barriers to testing, Latino respondents differ less from White respondents than AfricanAmerican respondents do. They do not differ significantly from Whites on the five-item knowledge index, and they are no less likely than White respondents to be described by interviewers as "very interested" in the survey topic and as displaying "excellent understanding." Nor do Latinos differ from Whites on various measures of confidence in institutions, trust, or political efficacy. They do, however, share African-Americans' concerns about privacy as well as about the potential misuse of genetic information.

For both Latinos and African-Americans, religious factors may play a role in reducing utilization of genetic testing. Frequency of church attendance is a significant negative predictor of preferences for testing as well as many other attitudes relevant to genetic technology, and African-Americans tend to attend church more frequently than either of the other groups. Self-identification as a Catholic is likewise related to negative attitudes toward testing, and Latinos are more likely to identify themselves as Catholic than either of the other groups. Although religion and religious attendance were controlled in all of the attitudinal analyses reported here, these factors may effectively reduce the utilization of genetic testing by African-Americans and Latinos.

Several findings reported in this article clearly call for further research. For example, although they express more concern about the potential misuse of genetic information, both African-American and Latino respondents seem to be less sensitive than White respondents to some possible abuses of ge- 
netic testing. They are less likely to consider prenatal testing for hair color, height, or weight as harmful, and less likely than White respondents to say that testing for genetic predispositions to behavioral characteristics like homosexuality or criminal behavior would do more harm than good. In response to questions not included in the present analysis, they are also less likely to say employers should not be allowed to administer genetic tests to prospective employees or to refuse to hire those whose tests show a predisposition to certain forms of heart disease and cancer. Research is needed to clarify the meaning of these responses, and their apparent contradiction with other responses indicating concern about potential misuse of genetic testing.

White respondents also tend to be much more restrictive in giving others access to private genetic information, even though, in response to a general question, they express less concern about privacy than African-American or Latino respondents do. It is possible that this is a matter of framing - perhaps African-American and Latino respondents understand the question about "who should have a right" to genetic information as conferring a benefit on others, whereas White respondents tend to see it as a violation of privacy, instead ( $c f$. Wertz, 1998). As noted earlier, this, too, is an area where further research is needed.

On many of these measures, Latino respondents interviewed in Spanish differed significantly in their responses from those interviewed in English. They were even more likely to say they would want both prenatal and adult genetic tests, and they were more likely to say they would want to abort the fetus in case of a serious genetic defect. They were significantly less likely to think testing for things like height, weight, hair color, criminality, or homosexuality would do more harm than good, and significantly more likely to believe that genetic testing would bring more good than harm in the long run. At the same time, they do not differ from Latino respondents interviewed in English in their concerns about possible misuse of genetic information or about privacy, even though they express more confidence in American institutions than respondents interviewed in English.

It is difficult to interpret this pattern of results. Latino respondents interviewed in Spanish are less likely to follow news about science and health, scored lower on the seven-item knowledge index, and were rated by interviewers as having less understanding of the survey topic than those interviewed in English. They also had significantly lower levels of education (54\%, for example, had less than 12 years of education, compared with $15 \%$ of those interviewed in English, and $8.8 \%$ had graduated from college, compared with $27.3 \%$ of those interviewed in English). One possibility, therefore, is that the responses described above simply reflect imperfect understanding of the questions, and a tendency to select the first response alternative offered by the interviewer.

Another possibility is that administering the questionnaire in Spanish had unanticipated consequences even though the translated instrument was reviewed by a bilingual interviewer and administered by interviewers fluent in both Spanish and English.

Unfortunately, we simply do not have enough information to decide among these alternatives, and here too much more research is clearly needed. Most survey questionnairesare not trans- lated into another language, with unknown consequences for the interpretation of results. (One possible consequence, of course, is that respondents not fluent in English are not interviewed at all.) We need to understand better both how to render questions and responses equivalent in other languages and how to interpret any remaining differences between respondents of similar ethnic background who are interviewed in different languages.

On the basis of the present survey, we cannot explain why African-Americans and Latinos differ from White respondents with respect to some of the attitudes expressed about genetic testing. However, although we cannot be sure of the reasons for differences where these exist, the survey clearly indicates that it is not less desire for the potential benefits of genetic testing that accounts for the lower utilization of this technology by African-Americans and Latinos. Rather, this seems to be attributable to a combination of fewer resources, less access to information, and greater concerns for the possible negative consequences of such tests.

\section{ACKNOWLEDGMENTS}

We gratefully acknowledge the financial support of the Robert Wood Johnson Foundation and the research assistance of Jenefer Willem and Emily McFarlane. The Zentrum für Umfragen, Methoden, and Analysen (ZUMA) provided support for the senior author in the revision of this article. Howard Schuman, Jennifer Barber, and Elizabeth Petty read an earlier draft of the manuscript and made helpful suggestions, as did members of a seminar on Life Sciences and Values organized at the University of Michigan by Professor Susan Goold.

\section{REFERENCES}

ANDRYKOWSKI, M.A., MUNN, R.K., and STUDTS, J.L. (1996). Interest in learning of personal genetic risk for cancer: a general population survey. Prev. Med. 25, 527-536.

ANDRYKOWSKI, M.A., LIGHTNER, R., STUDTS, J.L., and MUNN, R.K. (1997). Hereditary cancer risk notification and testing: how interested is the general population? J. Clin. Oncol. 15, 2139-2148. BILLINGS, P.R., KOHN, M.A., DE CUERVAS, M., BECKWITH, J., ALPER, J.S., and NATOWICZ, M.R. (1992). Discrimination as a consequence of genetic testing. Am. J. Hum. Genet. 50, 476-482.

BRETT, K.M., SCHOENDORF, K.C., and KIELY, J.L. (1994). Differences between black and white women in the use of prenatal care technologies. Am. J. Obstet. Gynecol. 170, 41-46.

CANTER, E. (1984). Employment discrimination: implications of genetic screening under Title VII and the Rehabilitation Act. Am. J. Law Med. 10, 323-347.

CITRIN, T., et al. (2001). Policy reports and recommendations, October 2001. Communities of Color and Genetics Policy Project, University of Michigan, Ann Arbor.

COMBS, M.W., and WELCH, S. (1982). Blacks, whites, and attitudes toward abortion. Publ. Opin. Q. 46, 510-520.

CROYLE, R.T., and LERMAN, C. (1993). Interest in genetic testing for colon cancer susceptibility: cognitive and emotional correlates. Prev. Med. 22, 284-292.

DRAPER, E. (1986). High risk workers on high risk work. Int. J. Sociol. Social Policy 6, 12-28.

DRAPER, E. (1991). Risky business. Cambridge University Press, New York. 
GRAHAM, I.D., LOGAN, D.M., HUGHES-BENZIE, R., EVANS, W.K., PERRAS, H., McAULEY, L.M., LAUPACIS, A., and STERN, H. (1998). How interested is the public in genetic testing for colon cancer susceptibility. Cancer Prev. Control 2, 167-172.

HALL, E.J., and FERREE, M.M. (1986). Race differences in abortion attitudes. Publ. Opin. Q. 50, 193-207.

HOLTZMAN, N.A. (1989). Proceed with caution. Johns Hopkins Press, Baltimore, MD.

INSTITUTE OF MEDICINE. (1994). Assessing genetic risks: implications for health and social policy. National Academy Press, Washington, DC.

KRIEGER, N., and WILLIAMS, D.R. (2001). Changing to the 2000 Standard Million: are declining racial/ethnic and socioeconomic inequalities in health real progress or a statistical illusion? Am. J. Publ. Health 91, 1209-1213.

NELKIN, D., and LINDEE, M.S. (1995). The DNA mystique: The gene as cultural icon. Freeman, New York.

NELKIN, D., and TANCREDI, L. (1989). Dangerous diagnostics. Basic Books, New York.

NEUMANN, P.J., HAMMITT, J.K., MUELLER, C., FILLIT, H.M., HILL, J., TETTEH, N.A., and KOSIK, K.S. (2001). Public attitudes about genetic testing for Alzheimer's disease. Health Affairs 20, 252-264.

SINGER, E. (1991). Public attitudes toward genetic testing. Popul. Res. Policy Rev. 10, 235-255.

SINGER, E. (1993). Public attitudes toward fetal diagnosis and the termination of life. Social Indic. Res. 28, 117-136.

SINGER, E., CORNING, A., and MARK LAMIAS, M. (1998). Trends: genetic testing, engineering, and therapy: awareness and attitudes. Public Opin. Q. 62, 633-664.

SINGER, E., CORNING, A., and ANTONUCCI, T. (1999). Attitudes toward genetic testing and fetal diagnosis, 1990-1996. J. Health Social Behav. 40, 429-445.
SINGER, E., MODELL, S., COE, S., CALDWELL, C., SCHULZ, A., and ANTONUCCI, T. (2001). Evaluation of dialogue process. Unpublished report, Ann Arbor, MI (April 25, 2001).

U.S. CONGRESS. OFFICE OF TECHNOLOGY ASSESSMENT. (1990). Genetic monitoring and screening in the workplace. U.S. Government Printing Office, Washington, DC.

UZYCH, L. (1986). Genetic testing and exclusionary practices in the workplace. J. Publ. Health Policy 7, 37-57.

WERTZ, D.C. (1998). The difficulties of recruiting minorities to studies of ethics and values in genetics. Commun. Genet. 1, 175-179.

WILCOX, C. (1990). Race differences in abortion attitudes: some additional evidence. Publ. Opin. Q. 54, 248-255.

WILLIAMS, D.R. (2002). Racial/ethnic variations in women's health: the social embeddedness of health. Am. J. Publ. Health 92, 588-597. WILLIAMS, D.R. (2001). Racial variations in adult health status: patterns, paradoxes, and prospects. America becoming: Racial trends and their consequences, vol. 2. In N.J. Smelser, W.J. Wilson, and F. Mitchell (eds.). National Academy Press, Washington, D.C.

WILLIAMS, D.R. (1999). Race, socioeconomic status, and health: the added effects of racism and discrimination. Ann. NY Acad. Sci. 896, 173-188

WILLIAMS, D.R., and COLLINS, C. (1995). U.S. socioeconomic and racial differences in health: patterns and explanations. Ann. Rev. Sociol. 21, 349-386.

Address reprint requests to: Eleanor Singer

Institute for Social Research

Box 1248

University of Michigan Ann Arbor, MI 48106

E-mail: esinger@isr.umich.edu 


\section{This article has been cited by:}

1. Phillis Lakeman, Anne Marie Catharina Plass, Lidewij Henneman, Pieter Dirk Bezemer, Martina Cornelia Cornel, Leo Pieter ten Kate. 2009. Preconceptional ancestry-based carrier couple screening for cystic fibrosis and haemoglobinopathies: what determines the intention to participate or not and actual participation?. European Journal of Human Genetics . [CrossRef]

2. Virginia L. Bartlett, Rolanda L. Johnson. 2009. God and genes in the caring professions: Clinician and clergy perceptions of religion and genetics. American Journal of Medical Genetics Part C: Seminars in Medical Genetics 151C:1, 41-51. [CrossRef]

3. Katarina M. Sussner, Hayley S. Thompson, Heiddis B. Valdimarsdottir, William H. Redd, Lina Jandorf. 2009. Acculturation and Familiarity With, Attitudes Towards and Beliefs about Genetic Testing for Cancer Risk Within Latinas in East Harlem, New York City. Journal of Genetic Counseling 18:1, 60-71. [CrossRef]

4. Kurt D. Christensen, J Scott Roberts, Charmaine D. M. Royal, Grace-Ann Fasaye, Thomas Obisesan, L Adrienne Cupples, Peter J. Whitehouse, Melissa Barber Butson, Erin Linnenbringer, Norman R. Relkin, Lindsay Farrer, Robert Cook-Deegan, Robert C. Green. 2008. Incorporating ethnicity into genetic risk assessment for Alzheimer disease: the REVEAL study experience. Genetics in Medicine 10:3, 207-214. [CrossRef]

5. Christina G. S. Palmer, Ariadna Martinez, Michelle Fox, Yvonne Sininger, Wayne W. Grody, Lisa A. Schimmenti. 2008. Ethnic Differences in Parental Perceptions of Genetic Testing for Deaf Infants. Journal of Genetic Counseling 17:1, 129-138. [CrossRef]

6. Mary K. Ethen, Mark A. Canfield, Jorge Trevino. 2007. Pilot test of prenatal surveillance for birth defects in South Texas. Birth Defects Research Part A: Clinical and Molecular Teratology 79:11, 788-791. [CrossRef]

7. Amy P. Case, Tunu A. Ramadhani, Mark A. Canfield, Catherine A. Wicklund. 2007. Awareness and Attitudes Regarding Prenatal Testing among Texas Women of Childbearing Age. Journal of Genetic Counseling 16:5, 655-661. [CrossRef]

8. Lei-Shih Chen, Patricia Goodson. 2007. Public Health Genomics knowledge and attitudes: A survey of public health educators in the United States. Genetics in Medicine 9:8, 496-503. [CrossRef]

9. Jeff Kendall, Colleen Kendall, Zohra Ali-Khan Catts, Cristi Radford, Kimberly Dasch. 2007. Using Adult Learning Theory Concepts to Address Barriers to Cancer Genetic Risk Assessment in the African American Community. Journal of Genetic Counseling 16:3, 279-288. [CrossRef]

10. Lisa Kessler, Aliya Collier, Chanita Hughes Halbert. 2007. Knowledge About Genetics Among African Americans. Journal of Genetic Counseling 16:2, 191-200. [CrossRef]

11. Anita Yeomans Kinney, Sara Ellis Simonsen, Bonnie Jeanne Baty, Diptasri Mandal, Susan L. Neuhausen, Kate Seggar, Rich Holubkov, Ken Smith. 2006. Acceptance of genetic testing for hereditary breast ovarian cancer among study enrollees from an African American kindred. American Journal of Medical Genetics Part $A$ 140A:8, 813-826. [CrossRef]

12. Diane C. Tucker, Ronald T. Acton, Nancy Press , Andrea Ruggiero , Jacob A. Reiss , Ann P. Walker, Lari Wenzel, Barbara Harrison, Margaret Fadojutimi-Akinsiku, Helen Harrison, Paul Adams, Jennifer A. Crabb , Roger Anderson, Elizabeth Thomson . 2006. Predictors of Belief That Genetic Test Information About Hemochromatosis Should Be Shared with Family MembersPredictors of Belief That Genetic Test Information About Hemochromatosis Should Be Shared with Family Members. Genetic Testing 10:1, 50-59. [Abstract] [PDF] [PDF Plus]

13. Kristine Barlow-Stewart, Soo See Yeo, Bettina Meiser, David Goldstein, Kathy Tucker, Maurice Eisenbruch. 2006. Toward cultural competence in cancer genetic counseling and genetics education: Lessons learned from Chinese-Australians. Genetics in Medicine 8:1, 24-32. [CrossRef]

14. P Preston Reynolds, Robert K. Kamei, Janet Sundquist, Niharika Khanna, Elissa J. Palmer, Trish Palmer. 2006. Using the PRACTICE Mnemonic to Apply Cultural Competency to Genetics in Medical Education and Patient Care. Academic Medicine 80:12, 1107-1113. [CrossRef] 